\title{
TEORI CATERING DAN KARAKTERISTIK KEUANGAN DALAM KEPUTUSAN DIVIDEN PERUSAHAAN BUMN DI INDONESIA
}

\author{
Fatmawati \\ F4teihsan@gmail.com \\ Rastina Ahmad \\ Jurusan Akuntansi Politeknik Negeri Ujung Pandang
}

\begin{abstract}
Dividend decision is a strategic policy relating to financial and investment decisions. Dividend policy is important to meet the expectations of shareholders. This study aims to investigates implication of the catering theory for dividend payers decision, and financial firm's characteristics on the probability of dividend payers decision. The study was conducted at State-Owned Enterprises listed in the Indonesia Stock Exchange. To test the prediction, the analytical method used logit regressions. The sampling technique purposive sampling. These samples included 110 state-owned enterprises during the period 2009-2014. The research data using state-owned company's financial statements by Indonesian Capital Exchange (IDX) and data from Indonesian Capital Market Directory (ICMD). Further data processing is done using SPSS for windows. The major finding that investor's demand for dividend payers has not signifikan effect on propensity that manager will decide to pay dividens thus catering theory predicted no effect on the company's decision to pay dividends. Profitability is financial firm's characteristic of decision dividend payers while free cash flow is not a financial characteristics of companies in the payment of dividends.
\end{abstract}

Key words: catering theory, profitability, free cash flow, prevailing investor demand,

\begin{abstract}
ABSTRAK
Keputusan dividen merupakan kebijakan strategis yang berkaitan dengan keputusan keuangan maupun investasi. Kebijakan dividen penting untuk memenuhi harapan para pemegang saham. Penelitian ini bertujuan untuk membuktikan prediksi teori catering dan karakteristik keuangan perusahaan yang memengaruhi keputusan perusahaan membayar dividen. Penelitian dilakukan pada perusahaan go public BUMN yang terdaftar di Bursa Efek Indonesia (BEI). Pengujian prediksi teori catering dan karakteristik keuangan perusahaan dalam melakukan pembayaran dividen dilakukan dengan menggunakan metode regresi Logistik. Teknik pengambilan sampel dengan purposive sampling. Sampel penelitian berjumlah 110 perusahaan BUMN selama periode 2009-2014. Data penelitian menggunakan laporan keuangan perusahaan BUMN yang diperoleh dari Indonesian Capital Exchange (IDX) dan data dari Indonesian Capital Market Directory (ICMD). Selanjutnya Pengolahan data dilakukan dengan menggunakan program SPSS for windows. Hasil penelitian menunjukkan permintaan investor akan dividen tidak berpengaruh signifikan terhadap kecenderungan manajer untuk membayar dividen, dengan demikian prediksi teori catering tidak berpengaruh dalam keputusan perusahaan untuk membayar dividen. Profitabilitas merupakan karakteristik keuangan perusahaan dalam membayar dividen sedangkan arus kas bebas bukan merupakan karakteristik keuangan perusahaan dalam pembayaran dividen.
\end{abstract}

Kata kunci: teori catering, profitabilitas, arus kas bebas, permintaan investor akan dividen

\section{PENDAHULUAN}

Dewasa ini sejumlah penelitian telah memberikan kontribusi pemikiran teoretis dan bukti empiris yang berkenaan dengan faktor penentu dari suatu kebijakan dividen perusahaan. Bhattacharyya (2007) menjelaskan bahwa kebijakan dividen merupakan suatu permasalahan yang paling sulit dan 
merupakan tantangan bagi para ahli ekonomi keuangan.

Pengaruh kebijakan dividen bagi investor, secara teoretis dikemukakan oleh Miller dan Modigliani (1961) bahwa tidak ada hubungan antara kebijakan pembagian dividen dengan nilai perusahaan. Bagaimanapun dalam praktek-praktek di pasar secara nyata, telah ditemukan bahwa kebijakan dividen nampaknya menjadi permasalahan. Melonggarkan satu atau lebih dari asumsiasumsi pasar modal yang sempurna adalah sebagai suatu dasar telah terbentuknya teoriteori yang menjadi tandingan dari teori kebijakan dividen tersebut.

Di negara maju seperti Amerika Serikat, perdebatan kebijakan dividen berfokus pada mengapa perusahaan membayar deviden. Telah diketahui bahwa pembayaran dividen akan dikenakan tarif pajak tinggi yang langsung dibayarkan pada saat dividen diterima. Negara dengan perlindungan terhadap investor yang relatif lemah, pertanyaan mengenai pembayaran dividen semakin relevan. Teori keagenan menyatakan bahwa pemegang saham publik (outsider) memiliki preferensi yang lebih tinggi terhadap dividen daripada laba ditahan (Jensen, 1986). Preferensi terhadap dividen akan semakin tinggi pada negara-negara berkembang yang kurang memiliki perlindungan terhadap investor, terutama jika pemegang saham outsider mempersepsikan terdapat risiko yang akan dilakukan pemegang saham insider (La Porta, 1997 (dalam Ferris et al., 2009)).

Kajian ilmiah yang turut berperan dalam merumuskan teori untuk menjelaskan mengapa perusahaan harus membayar dividen atau tidak harus membayar dividen disampaikan oleh Baker dan Powell (1999). Alternatif pemikiran tentang dividen diusulkan oleh DeAngelo dan DeAngelo (2006) bahwa kebijakan payout yang optimal didorong oleh kebutuhan mendistribusikan arus kas bebas (free cash flow) perusahaan. Mereka mengusulkan suatu teori life-cycle, dengan menggabungkan elemen teori ke- agenan (Jensen, 1986) dengan evolusi dalam set kesempatan investasi perusahaan (investment opportunity set) (Fama dan French, 2001 dan Grullon et al., (2002) dalam Denis dan Osobov (2008).

Teori baru yang berkembang saat ini tentang dividen dikemukakan oleh Baker dan Wurgler (2004a) dikenal dengan nama teori catering dividen (catering theory of dividens). Teori catering dividen mengusulkan bahwa kebijakan dividen perusahaan didorong oleh permintaan investor atas pembayaran dividen dan manajer akan melayani investor dengan membayar dividen ketika dividen premium tinggi. Baker dan Wurgler (2004a) menyatakan argumennya bahwa manajer akan secara oportunis memodifikasi kebijakan pembayaran (payout) ketika sentimen investor mendukung pembayaran dividen. Pada makalah selanjutnya, Baker dan Wurgler (2004b) memberikan penjelasan catering terhadap penurunan persentase pembayaran dividen yang tidak diharapkan pada perusahaan-perusahaan di Amerika.

Teori catering berbeda dengan pandangan umum tentang pengaruh permintaan investor terhadap kebijakan dividen. Pandangan umum menekankan bahwa kebijakan dividen tidak relevan terhadap harga saham bahkan ketika beberapa kelompok investor mempunyai pilihan rasional atas dividen. Teori catering menekankan pada permintaan investor akan dividen dipengaruhi oleh sentimen pasar, oleh karena itu prediksi utama teori ini adalah kecenderungan untuk membayar dividen tergantung pada deviden premium yang dapat terukur dari harga saham. Teori catering ini merupakan hal baru yang diusulkan oleh Baker dan Wurgler (2004a) sebagai pengembangan asumsi teori dividen relevan Miller dan Modigliani (1961).

Teori catering telah dirujuk oleh para peneliti diberbagai negara antara lain Li dan Lie (2005) memberikan konfirmasi lebih lanjut tentang efek catering pada perusahaan di Amerika melalui pengujian perubahan 
rasio payout perusahaan dan hubungannya dengan dividen premium pasar (market dividen premium). Ferris et al. (2009) menginvestigasi kebijakan dividen di Inggris dan menyimpulkan bahwa pergeseran insentif catering, yang paling mungkin menjelaskan kecenderungan penurunan pembayaran dividen selama periode 1988-2002.

Bukti terkait dividen catering masih terbatas dan bervariasi. Antara lain Temuan oleh Denis dan Osobov (2008) bahwa di Negara common law (Kanada dan Inggris), pemegang saham memberikan tekanan yang kuat pada manajer terbukti mendukung teori catering namun dengan signifikansi yang rendah. Sementara pada negara-negara dengan hukum perdata (civil law) seperti Jerman, Perancis dan Jepang, yang pemegang sahamnya memberikan tekanan yang rendah (low pressure) terhadap manajer, teori catering ini ditolak. Hal ini sejalan dengan Tsuji (2011) melakukan pengujian teori catering dividen pada perusahaan industri kimia dan peralatan elektrik di Jepang yang menemukan bahwa manajer perusahaan di Jepang tidak mempertimbangkan perilaku catering dalam kebijakan memulai maupun melanjutkan pembayaran dividen. Sebaliknya Neves et al., (2011) menemukan bahwa sentimen investor berdampak terhadap rasio payout pada perusahaan-perusahaan di zona euro.

Pasar modal Indonesia terus mengalami perkembangan yang ditandai dengan salah satu indikator yakni meningkatnya jumlah emiten. Adanya kecenderungan emiten di BEI mengurangi pembayaran dividen dimana pasca 1998 , hanya $40 \%$ dari korporasi yang menghasilkan laba bersih yang membagikan dividen. Bahkan berdasarkan keterangan para emiten yang dirangkum oleh BEI, terdapat delapan perusahaan di Indonesia yang tidak membagikan dividen dalam tiga tahun terakhir meskipun menghasilkan laba bersih, antara lain PT Hero Supermarket Tbk, sebagaimana Microsof yang baru bersedia membayar dividen setelah 17 tahun go public.
Fenomena ini menimbulkan pertanyaan, jika pembagian dividen merupakan good news atau berita baik, mengapa terdapat perusahaan yang enggan membagikan dividen meskipun perusahaannya berlaba dan mengapa semakin sedikit perusahaan yang membagikan dividennya. Penurunan pembayaran dividen atau perubahan dalam jumlah yang dibayar oleh perusahaan atas dividen ini dijelaskan teori catering dividen dengan memberikan bukti empiris bahwa perubahan dalam jumlah yang dibayar atas pembayaran dividen dapat dijelaskan oleh apa yang disebut sebagai catering yaitu ukuran keinginan pasar untuk membayar dividen atas saham (Baker dan Wurgler, 2004b).

Perbedaan hasil penelitian dan beberapa penelitian terdahulu yang telah dikemukakan merupakan research gap dalam penelitian ini. Studi ini menekankan pada kebijakan pembayaran dividen perusahaan publik di Indonesia. Kebijakan pembayaran dividen di Indonesia telah banyak diteliti namun penulis memasukkan variabel insentif catering sebagai faktor penentu pembayaran dividen di Indonesia, yang membedakan dengan penelitian sebelumnya.

Baker dan Wurgler (2004a) mengemukakan bahwa pasar modal tidak selalu efisien dalam menelaah informasi, oleh karena itu keputusan membagikan dividen tergantung pada minat investor dan respon pasar terhadap dividen. Manajemen sebaiknya membagikan dividen jika pasar memberikan nilai lebih (premium) pada perusahaan pembagi dividen dan sebaliknya tidak memberikan dividen jika pasar tidak memberi premium pada perusahaan pembagi dividen. Teori catering dinamakan oleh Baker dan Wurgler (2004a) mengemukakan bahwa perusahaan akan menyesuaikan pembayaran dividen dalam merespon permintaan investor atas dividen. Studi terkait teori catering dilakukan oleh Handary et al., (2008), meneliti hubungan antara insentif catering dengan return saham. Sampel pe- 
nelitian sebanyak 337 perusahaan nonkeuangan yang terdaftar di Bursa Efek Jakarta yang terdiri dari 363 pengumuman dividen selama periode 1999-2003. Korelasi antara insentif catering yang diukur dengan dividen premium menunjukkan hubungan yang negatif dengan return saham. Mereka mengemukakan bahwa hubungan negatif tersebut mungkin disebabkan oleh peluang pertumbuhan relatif perusahaan, dimana hal ini ditunjukkan oleh penurunan jumlah pembayar dividen selama periode pengamatan. Hasil studi lainnya tentang faktor penentu kebijakan dividen oleh emiten di Indonesia dilakukan Arilaha (2009), Hadianto dan Herlina (2010) dan Kurniasih (2011). Temuan Arilaha (2009) profitabilitas memiliki pengaruh yang signifikan terhadap kebijakan dividen. Arus kas bebas, leverage dan likuiditas tidak berpengaruh signifikan terhadap kebijakan dividen. Hadianto dan Herlina (2010) berdasarkan hasil studi pada indeks kompas 100 pada tahun 2007 menyatakan kebijakan utang dan profitabilitas berpengaruh positif terhadap kebijakan dividen sedangkan arus kas bebas tidak berpengaruh terhadap kebijakan deviden. Kurniasih (2011) menemukan bahwa perusahaan-perusahaan yang terdaftar di BEI membayarkan dividen tidak stabil dan memiliki target rasio payout untuk jangka panjang.

Latar belakang masalah atau fenomena yang telah dikemukakan di atas, guna mendukung penelitian empiris, pertanyaan penelitian yang dirumuskan untuk dikembangkan dalam penelitian ini, sebagai berikut. (1) Apakah prediksi teori catering dividen berpengaruh dalam keputusan pembayaran dividen pada perusahaan BUMN di Bursa Efek Indonesia? (2) Bagaimana karakteristik keuangan perusahaan dalam keputusan pembayaran dividen perusahaan BUMN di Bursa Efek Indonesia?. Berdasarkan permasalah yang telah dipaparkan sebelumnya maka tujuan penelitian ini adalah untuk (1) Mengetahui prediksi teori catering dalam keputusan pembayaran dividen pada perusahaan BUMN di Bursa Efek Indonesia. (2) Mengetahui karakteristik keuangan perusahaan dalam keputusan pembayaran dividen pada perusahaan BUMN di Bursa Efek Indonesia.

\section{TINJAUAN TEORETIS}

Dividen menurut Warsono (2003), merupakan pembagian sisa laba bersih perusahaan yang didistribusikan kepada pemegang saham yang biasanya diberikan dalam bentuk tunai. Dividen dibagikan atas persetujuan RUPS (Rapat Umum Pemegang Saham. Dividen yang dibagikan dapat berupa uang tunai atau cash dividend yang artinya setiap pemegang saham diberikan dividen berupa uang tunai dalam jumlah tertentu untuk setiap lembar saham, atau dibagikan stock dividend yang nantinya akan menambah jumlah saham yang dimilikinya. Kebijakan dividen merupakan keputusan apakah laba yang dihasilkan perusahaan akan dibagikan dalam bentuk dividen atau dalam bentuk laba ditahan sebagai penambah modal untuk pendanaan investasi di masa yang akan datang (Warsono, 2003).

\section{Faktor yang Memengaruhi Kebijakan Dividen}

Semakin tinggi dividen yang dibagikan kepada pemegang saham akan mengurangi kesempatan perusahaan untuk mendapatkan sumber dana intern dalam rangka mengadakan reinvestasi. Hal ini dalam jangka panjang akan menurunkan nilai perusahaan, sebab pertumbuhan dividen akan semakin berkurang, oleh karena itu manajemen perusahaan harus menentukan kebijakan dividen yang optimal agar bisa menjaga nilai perusahaan. Sutrisno (2009: 305) menjelaskan tentang faktor-faktor yang memengaruhi kebijakan dividen yaitu posisi solvabilitas perusahaan, likuiditas, kebutuhan dana untuk membayar hutang, rencana perluasan usaha, kesempatan investasi, stabilitas pendapatan dan pengawasan terhadap perusahaan. 
Jensen (1986) mendefinisikan arus kas bebas sebagai kas yang tersisa setelah seluruh proyek yang menghasilkan net present value positif dilakukan. Perusahaan dengan arus kas bebas berlebih akan memiliki kinerja yang lebih baik dibandingkan perusahaan lainnya. Perusahaan dengan arus kas bebas tinggi diduga lebih survive dalam situasi yang buruk. Arus kas bebas yang negatif berarti sumber dana internal tidak mencukupi pemenuhan kebutuhan investasi perusahaan sehingga memerlukan tambahan dana eksternal baik dalam bentuk hutang maupun penerbitan saham baru.

Wild et al., (2007) menyatakan turunan analitis laporan arus kas yang bermanfaat adalah penghitungan arus kas bebas (free cash flow). Meskipun tidak ada kesepakatan atas definisi pasti untuk arus kas bebas, salah satu ukuran arus kas bebas adalah sebagai berikut: $F C F=$ Arus kas operasional pengeluaran modal untuk mempertahankan kapasitas produksi - dividen untuk saham preferen dan biasa.

\section{Teori tentang Kebijakan Dividen}

Teori Dividen Tidak Relevan (Irrelevant Dividend Theory)

Miller dan Modigliani (1961) berpendapat bahwa pada dasarnya pada kondisi keputusan investasi yang sudah given, pembayaran dividen tidak relevan untuk diperhitungkan, karena tidak akan meningkatkan kesejahteraan pemegang saham. Dividen bukan preferensi para pemegang saham biasa untuk dividen sekarang (lebih baik daripada capital gain mendatang) yang responsible terhadap perilaku ini. Perubahan dalam dividen naik atau turun, dipandang sebagai sinyal (signal) bahwa manajemen mengharapkan laba di masa mendatang mengubah dalam arah yang sama.

\section{Teori Dividen Relevan}

Teori dividen relevan menyatakan semakin tinggi dividen payout ratio maka harga saham akan semakin tinggi. Teori dividen relevan yang dikenal dengan teori the bird in the hand menyatakan bahwa biaya modal sendiri perusahaan akan naik jika dividend payout rendah karena investor lebih suka menerima dividen daripada capital gains. Teori ini dikemukakan oleh Gordon (1963) dan Lintner (1962).

\section{Teori Dividen Signal (Dividend Signaling Theory)}

Dividend signaling theory pertama kali dicetuskan oleh Bhattacharya (1979). Teori ini mendasari dugaan bahwa pengumuman perubahan cash dividend mempunyai kandungan informasi yang mengakibatkan munculnya reaksi harga saham. Teori ini menjelaskan bahwa informasi tentang cash dividend yang dibayarkan dianggap investor sebagai sinyal prospek perusahaan di masa mendatang.

\section{Teori Catering Dividen}

Catering theory of dividens ini dikemukakan oleh Baker dan Wurgler (2004a). Sebagai upaya untuk memperbaiki teori MM, berpendapat bahwa pasar tidak selalu efisien dalam menelaah informasi. Keputusan untuk membayar dividen didorong oleh permintaan investor. Manajemen sebaiknya membagikan dividen jika pasar memberi nilai lebih (premium) pada perusahaan pembagi dividen. Sebaliknya manajemen perusahaan jangan membagikan dividen jika pasar tidak memberi premium pada perusahaan pembagi dividen. Dengan kata lain manajer melayani investor dengan membayar dividen ketika investor menempatkan premi harga saham pada perusahaan pembayar dividen dan tidak membayar ketika investor memilih untuk tidak dibayar. Perbedaan teori dividen catering dengan teori-teori dividen yakni clientele equilibrium yaitu teori catering menekankan pada kemungkinan permintaan investor akan dividen dipengaruhi oleh sentimen pasar, teori catering lebih berfokus pada permintaan atas saham untuk pembayaran dividen. Prediksi utama dari teori catering adalah kecenderungan untuk membayar dividen tergantung pada premi dividen yang dapat terukur dari harga saham. 


\section{Agency Theory}

Adanya perbedaan kepentingan antara manajer dan pemilik perusahaan (principal) maupun investor menjadi isu penting dalam perusahaan. Perbedaan kepentingan tersebut sering disebut dengan masalah keagenan (agency problem). Masalah keagenan akan menimbulkan biaya yang disebut biaya keagenan. Dalam mengatasi masalah ini, dividen dapat digunakan sebagai alat untuk meminimalkan biaya yang timbul karena adanya perbedaan kepentingan. Jensen (1986) berargumen bahwa manajer pada perusahaan publik memiliki insentif untuk melakukan ekspansi perusahaan melebihi ukuran optimal, meskipun ekspansi tersebut dilakukan pada proyek yang memiliki net present value (NPV) negatif. Kondisi overinvestment ini dilakukan dengan menggunakan dana internal yang dihasilkan oleh perusahaan dalam bentuk free cash flow. Masalah free cash flow merujuk pada aktivitas manajer yang lebih menyukai melakukan investasi (meskipun dengan NPV negatif) daripada membaginya dalam bentuk dividen.

\section{Penelitian Terdahulu}

Para peneliti telah mengajukan banyak teori yang berbeda tentang faktor-faktor yang memengaruhi kebijakan dividen perusahaan. Beberapa teori itu meliputi biaya keagenan, informasi asimetris (signaling) dan penjelasan-penjelasan perilaku. Sementara itu, para peneliti lainnya mempunyai usulan model pengembangan dan pengujian empiris yang berbeda untuk dapat menjelaskan tentang perilaku dividen.

Hasil studi Lintner (1956) menyatakan bahwa faktor-faktor yang memengaruhi kebijakan dividen adalah tingkat laba baik untuk periode yang bersangkutan maupun harapan tingkat laba untuk periode-periode yang akan datang, dan pola pembayaran dividen sebelumnya. Fama dan Babiak (1968) menemukan bukti bahwa perubahan dalam dividend per share suatu perusahaan pada umumnya adalah suatu fungsi dari target dividend payout ratio perusahaan, laba periode berjalan dan laba yang lalu, dan dividen periode sebelumnya.

Studi tentang teori dividen catering dilakukan oleh Li dan Lie (2005) yang memperpanjang penelitian teori catering Baker dan Wurgler (2004a). Menggunakan metode dokumentasi data keuangan dengan sampel 1.815 penurunan dividen dan 18.964 peningkatan dividen selama tahun 1963-2000 melakukan pengujian dengan metode multinomial logistic regression. Mereka menemukan bahwa keputusan tentang perubahan dividen dan besaran perubahan bergantung pada premium pasar modal yang ditempatkan atas dividen. Dengan demikian pasar modal memberikan penghargaan terhadap manajer yang mempertimbangkan permintaan investor akan dividen ketika melakukan pengambilan keputusan tentang tingkat dividen.

Di pasar modal Inggris, Ferris et al. (2009), mengeksplorasi dan melakukan validasi teori catering dividen dengan menggunakan metode dokumentasi di pasar modal Inggris. Mereka menemukan bahwa dividen menghilang setelah tahun 1990 dan hilangnya berhubungan dengan tingkat premi dividen yang sangat rendah. Neves et al. (2011) melakukan studi dan memvalidasi hubungan antara tingkat pembayaran deviden dengan teori catering pada perusahaan di zona Euro. Hasil penelitian ini menyatakan perusahaan-perusahaan di Zona Euro memberikan kepuasan terhadap sentimen investornya. Hal ini menunjukkan adanya hubungan antara pembayaran dividen dengan teori Catering.

Denis dan Osobov (2008) juga melakukan pengujian teori catering. Menggunakan data time series untuk 6 pasar modal yang berkembang antara tahun 1994 dan 2002. Hasil menunjukkkan bahwa di Kanada dan Inggris, dimana para pemegang saham memberikan tekanan yang cukup kuat terhadap para manajer, teori catering ini terverifikasi namun signifikansinya kecil. Sementara di Jerman, Prancis dan Jepang, 
dimana tekanan para shareholder terhadap para manajer kurang, teori catering ini di tolak.

Ferris et al. (2009) membuktikan hasil dari Denis dan Osobov (2008) pada sampel di 23 negara. Manajer secara rasional merespon permintaan investor akan dividen di Negara-negara dengan hukum common law. Sebaliknya di negara-negara hukum sipil atau perdata (civil law), perusahaan tidak mengikuti preferensi investor akan dividen. Studi terkini yang dilakukan oleh Albouy et al. (2010) memvalidasi teori catering dengan melakukan survey terhadap 75 manajer di perusahaan-perusahaan yang listing di Perancis. Terdapat $64 \%$ manajer yang merespon secara positif, hanya $18 \%$ yang menjawab negatif.

Penelitian tentang teori dividen catering di Asia oleh Tsuji (2011) melakukan penelitian terhadap perilaku pembayaran dividen pada industri kimia di Jepang. Menggunakan data perusahaan kimia yang membayar dividen dan tidak membayar dividen selama tahun 1987 sampai dengan 2006. Hasil penelitian mengungkapkan, dividen premium bukan merupakan faktor penentu atau determinan dalam menginisiasi maupun melanjutkan pembayaran dividennya. Hal ini berarti perusahaan industri kimia di Jepang tidak berperilaku sebagaimana yang diindikasikan pada teori catering.

\section{Rerangka konseptual dan hipotesis}

Pengujian teori catering dividen dimaksudkan untuk melihat apakah perusahaan-perusahaan yang terdaftar di pasar modal Indonesia khususnya pada perusahaan Indeks Bisnis E-27 mempertimbangkan perilaku catering dalam kebijakan dividennya. Sebagaimana yang diusulkan Baker dan Wurgler (2004a) dalam teori catering dividennya yang menyatakan bahwa keputusan membagikan dividen tergantung dari minat investor dan respon pasar terhadap dividen. Perusahaan membagikan dividen dan menyesuaikan pembayaran dividennya berdasarkan perminta- an investor akan dividen. Permintaan investor ini dimaknai sebagai sentimen pasar yang diukur dengan dividen premium. Karakteristik keuangan perusahaan menjadi faktor penentu (determinant) pem- bayaran dividen dikemukakan oleh Lintner (1956) bahwa faktor laba perusahaan yang menjadi kunci pola dividen yang stabil. Demikian pula teori free cash flow Jensen (1986) mengemukakan dividen dapat digunakan sebagai alat monitor para manajer mempertanggungjawabkan kinerjanya. Peningkatan dividen mengakibatkan tidak tersedianya banyak free cash flow, dengan demikian akan mengurangi masalah keagenan.

Berdasarkan uraian di atas maka secara keseluruhan implikasi teori catering dan faktor penentu keuangan perusahaan dalam kebijakan dividennya dapat ditunjukkan pada gambar 1 .

\section{Teori Catering Dividen dengan Kebijakan Dividen}

Baker dan Wurgler (2004b) mengukur sentimen investor melalui perbedaan antara logaritma rasio pasar berbanding nilai buku rata-rata tertimbang untuk perusahaan pembayar dividen dan perusahaan yang tidak membayarkan dividen. Mereka menemukan bahwa hubungan positif antara insentif catering ditangkap oleh premi dividen (dividen premium). Secara umum hasil-hasil studi yang membahas mengenai teori catering dividen masih terdapat perbedaan hasil. Perilaku pengambilan keputusan berkaitan dengan dividen oleh manajemen di Negara yang berbeda kultur dan perbedaan dari sisi hukum menunjukkan keragaman hasil. Sebagaimana pemaparan Frankfurter dan Wood (1997) bahwa model kebijakan dividen lebih dari sekadar model perilaku.

Pengujian teori catering telah dikonfirmasi di pasar Amerika, Kanada dan Inggris, yang diklasifikasikan sebagai negara common law, demikian pula Perancis sebagai klasifikasi Negara civil law. Temuan di pasar Perancis terdapat dua hasil berbeda yakni dua hasil yang menolak teori catering (Denis 


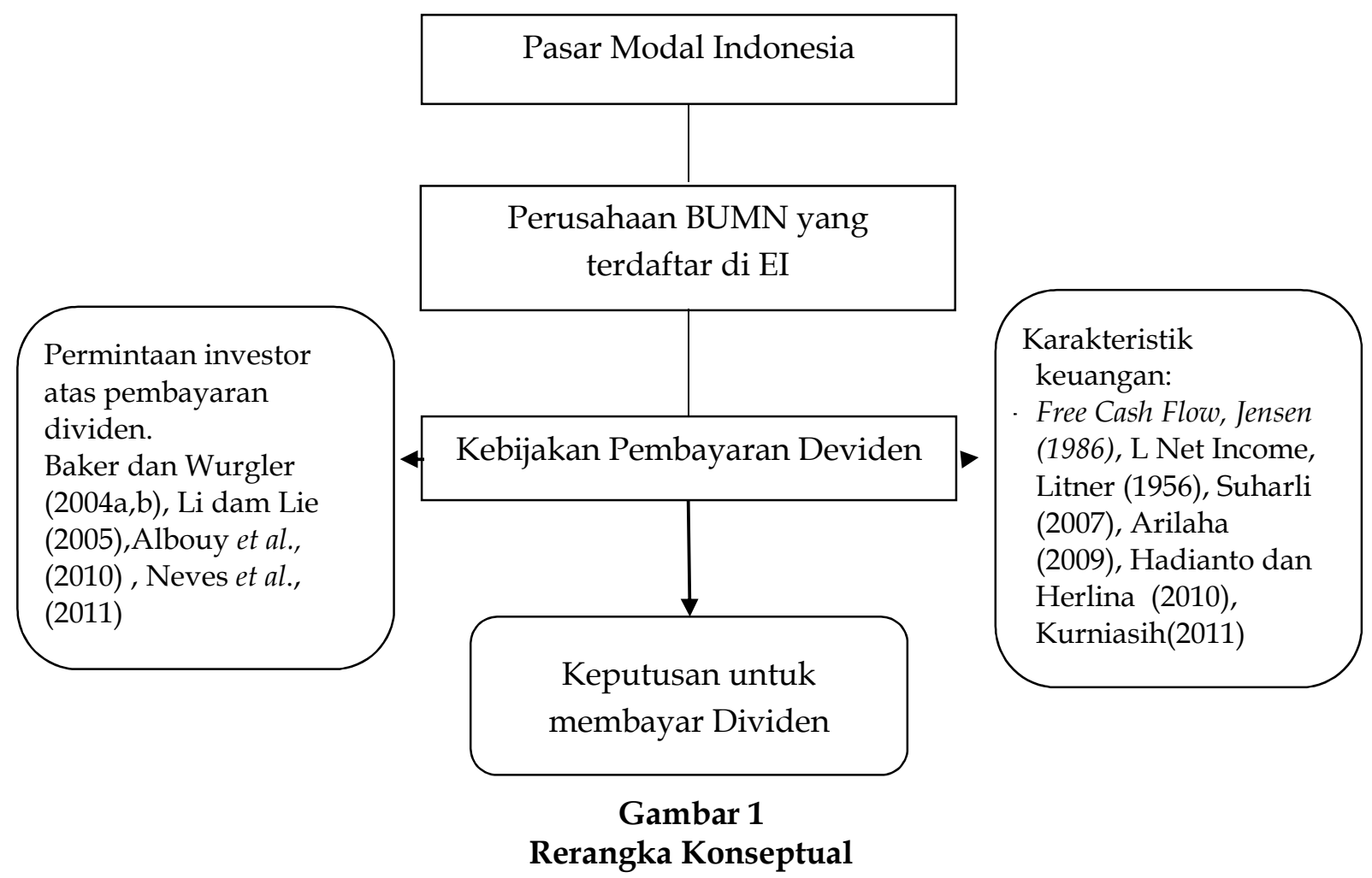

dan Osobov, 2008; Ferris et al., 2009) dan satu yang menerima teori catering (Albouy et al., 2010). Berdasarkan teori dan hasil-hasil penelitian terdahulu yang terkait dengan penelitian ini, maka peneliti mengembangkan hipotesis penelitian sebagai berikut.

$\mathrm{H}_{1}$ : Perusahaan BUMN di Bursa Efek Indonesia mempertimbangkan perilaku catering dalam keputusan pembayaran dividen

\section{Teori Tradisional Dividen}

Pembayaran dividen kas merupakan arus kas keluar. Semakin kuat posisi kas perusahaan berarti semakin besar kemampuan perusahaan untuk membayar dividen kepada pemegang saham. Salah satu pengurang konflik keagenan adalah dividen. Jensen (1986) dengan teori free cash flow nya menyatakan bahwa suatu perusahaan dengan free cash flow yang substansial cenderung mengadopsi proyekproyek investasi dengan nilai sekarang netto (net present value) yang negatif. Hubungan positif antara dividen dan free cash flow telah dikonfirmasi oleh Chaplinsky dan Niehaus
(1993), Holder et al. (1998) dalam Neves et al. (2011). Studi terkini oleh DeAngelo, DeAngelo dan Stulz (2004) dalam Ferris et al. (2009) menunjukkan proses investasi berlebihan yang salah dalam perusahaan mengakibatkan proporsi kas yang tinggi dan distribusi dividen yang rendah.

Meskipun banyak penelitian yang menemukan hubungan positif antara dividen dan arus kas bebas, namun di Indonesia temuan ini cenderung beragam. Arilaha (2009), Hadianto dan Herlina (2010) menyimpulkan bahwa arus kas bebas tidak berpengaruh signifikan dalam kebijakan dividen. Profitabilitas merupakan faktor penentu kemungkinan dibayarkannya dividen. Penelitian yang menemukan pengaruh signifikan antara free cash flow terhadap pembayaran dividen dilakukan oleh Lucyanda dan Lilyana (2012). Konsisten dengan teori Jensen dan bukti empiris yang telah dikemukakan, maka hipotesis berikut ini:

$\mathrm{H}_{2}$ : Arus kas bebas (free cash flow) secara positif memengaruhi keputusan pembayaran dividen perusahaan. 
Salah satu studi yang relevan dengan faktor penentu (determinant) dari dividen dikemukakan oleh Lintner (1956) bahwa faktor laba perusahaan (earnings) yang menjadi faktor kunci suatu pola dividen yang stabil. Suharli (2007) menyimpulkan bahwa kebijakan jumlah pembagian dividen dipengaruhi oleh profitabilitas yang diperkuat oleh likuiditas perusahaan, oleh karena itu, peneliti mengemukakan hipotesis berikut:

$\mathrm{H}_{3}$ : Profitabilitas berpengaruh positif terhadap keputusan perusahaan untuk membayar dividen

\section{METODE PENELITIAN}

Penelitian ini dilakukan pada perusahaan BUMN yang terdaftar di Bursa Efek Indonesia (BEI) melalui otoritas Pusat Informasi Pasar Modal (PIPM) wilayah Makassar, Jl. Andi Pangeran Pettarani, Makassar. Lama waktu penelitian akan dilakukan selama 1 tahun.

\section{Populasi dan Sampel}

Populasi penelitian ini adalah perusahaan BUMN publik yang terdaftar di Bursa Efek Indonesia sebanyak 20 emiten. Pemilihan sampel dilakukan dengan metode purposive sampling. Sampel pada penelitian ini adalah perusahaan Badan Usaha Milik Negara (BUMN) yang membagikan dividen maupun tidak membagi dividen tunai dan datanya tersedia. Data yang digunakan dalam penelitian ini adalah data sekunder meliputi data keuangan perusahaan yang membayar dividen dan yang tidak membayar dividen pada tahun 2009 sampai dengan 2014. Data penelitian ini diperoleh dari capital market directory Bursa Efek Indonesia dan website (www.idx. co.id).

\section{Teknik Pengumpulan Data}

Pengumpulan data yang dilakukan adalah dengan metode dokumentasi, teknik pengambilan data dengan mencari dan mengumpulkan data laporan keuangan dan/ atau annual report serta ringkasan (summary) kinerja perusahaan BUMN yang dipublikasi kan.

\section{Definisi Operasional Variabel}

Variabel yang dgunakan dalam penelitian ini adalah keputusan pembayaran dividen (dividend payment decision) yang dilambangkan dengan Y. Keputusan pembayaran dividen adalah variabel dependen yang bersifat kualitatif, oleh karena itu agar regresi dapat dilakukan variabel kualitatif ini dikuantitifkan dengan memberikan nilai 1 jika variabel mempunyai atribut dan nilai 0 jika tidak mengandung atribut (Widarjono, 2010). Berikut adalah operasionalisasi variabel penelitian.

\section{Teknik Analisis Data}

Peneliti menggunakan metodologi kuantitatif regresi logistik dalam menguji hipotesis yang diajukan. Regresi logistik digunakan untuk mengetahui pengaruh variabel independen terhadap variabel dependen yang bersifat biner atau bersifat kualitatif yang mempunyai dua kelas atau kategori (binary). Variabel terikat (dependent variable) pada penelitian ini adalah keputusan untuk membayarkan dividen. Dalam hal ini digunakan regresi variabel dependen kualitatif dengan pendekatan probabilitas logit (binary logit), oleh karena itu untuk variabel kualitatif diberikan angka atau nilai 1 untuk pembayar dividen dan 0 untuk yang bukan pembayar dividen. Model logit yang digunakan dalam pengujian implikasi teori catering dan karakteristik keuangan perusahaan untuk memulai atau melanjutkan membayar dividen adalah: $\mathrm{Y}=\beta 0+\beta 1 \mathrm{M} / \mathrm{B}$ $+\beta 2 \mathrm{FCF}+\beta 3 \mathrm{DY}+\beta 4 \mathrm{POR}+\varepsilon$ Keterangan:

Y : 1 jika perusahaan adalah pembayar dividen, 0 tidak membayar dividen;

FCF : Free cash flow

NI : Net Income

M/B : Rasio pasar per nilai buku

B : Beta

E : Errors, random efek 
Tabel 1

Operasionalisasi Variabel

\begin{tabular}{|c|c|c|c|c|}
\hline No & $\begin{array}{c}\text { Nama } \\
\text { variabel }\end{array}$ & Pengertian & Indikator & Skala \\
\hline 1. & $\begin{array}{l}\text { Keputusan } \\
\text { pembayaran } \\
\text { dividen }(Y)\end{array}$ & $\begin{array}{l}\text { Keputusan perusahaan untuk } \\
\text { membayar dividen }\end{array}$ & $\begin{array}{l}\text { Variabel binary nilai } 1 \\
\text { untuk pembayar divi- } \\
\text { den dan } 0 \text { untuk yang } \\
\text { tidak membayar divi- } \\
\text { den }\end{array}$ & Nominal \\
\hline 2. & $\begin{array}{l}\text { Permintaan } \\
\text { investor } \\
(\mathrm{MB})\end{array}$ & $\begin{array}{l}\text { Ukuran keinginan pasar akan } \\
\text { permintaan dividen (Baker } \\
\text { dan Wurgler, 2004a) }\end{array}$ & $\begin{array}{l}\text { (Book assets - book } \\
\text { equity + market equity) } \\
\text { dibagi book assets pada } \\
\mathrm{t}-1\end{array}$ & Rasio \\
\hline 3. & $\begin{array}{l}\text { Arus kas } \\
\text { bebas (free } \\
\text { cash flow) }\end{array}$ & $\begin{array}{l}\text { Arus kas bersih diakhir peri- } \\
\text { ode keuangan setelah biaya } \\
\text { operasional dan belanja mo- } \\
\text { dal untuk pengembangan } \\
\text { usaha (Wild et al., 2007) }\end{array}$ & $\begin{array}{l}\text { Arus kas dari operasi } \\
\text { dikurangi belanja } \\
\text { modal pada t-1 }\end{array}$ & Rasio \\
\hline 4. & $\begin{array}{l}\text { Profitabilitas } \\
\text { (profitability) }\end{array}$ & $\begin{array}{l}\text { laba dari bisnis perusahaan } \\
\text { yang sedang berjalan setelah } \\
\text { bunga dan pajak }\end{array}$ & $\begin{array}{l}\text { Laba bersih setelah } \\
\text { dikurangi pajak }\end{array}$ & Rasio \\
\hline
\end{tabular}

Hasil regresi logistik sebagai salah satu bentuk analisis regresi memerlukan suatu evaluasi untuk memahami seberapa baik hasil regresi logistik yang dilakukan (Widarjono, 2010:139). Evaluasi hasil regresi logistik meliputi: (a) Penilaian seberapa baik (goodness of fit) model regresi atau menilai kelayakan model regresi (uji kualitas data). Uji goodness of fit dalam regresi logistik adalah untuk mengetahui kebaikan model. Ukuran kebaikan garis regresi di dalam regresi logistik disebut Pseudo $\mathrm{R}^{2}$. Nilai Cox dan Snell R Square akan menunjukkan variabel independen di dalam model logit mampu menjelaskan persentase perilaku perusahaan dalam melakukan pembayaran dividen atau tidak; (b) Uji signifikansi pengaruh semua variabel independen secara serentak terhadap variabel dependen (overall model fit).

Perhatikan output Omnibus Tests of Mode Coefficients, dengan hipotesis; $\mathrm{H}_{0}$ : tidak ada variabel $X$ yang signifikan memengaruhi variabel $\mathrm{Y}$ nya; $\mathrm{H}_{1}$ : minimal ada satu variabel yang signifikan memengaruhi variabel $Y$ nya.
1. Jika probabilitas $>0,05$ maka $\mathrm{H}_{0}$ ditolak dan $\mathrm{H}_{1}$ diterima, yang berarti minimal ada satu variabel $X$ yang signifikan memengaruhi variabel $Y$.

2. Jika probabilitas $\leq 0,05$ maka $\mathrm{H}_{0}$ diterima dan $\mathrm{H}_{1}$ ditolak, yang berarti tidak ada variabel $X$ yang signifikan memengaruhi variabel Y.

(c) Uji signifikasi pengaruh variabel independen terhadap variabel dependen secara individual (significance test)

Pada model binary logit, interpretasi penting dalam model regresi multinomial logit bukan pada koefisien B tetapi pada koefisien Exp (B). Pengujian dilakukan dengan menggunakan significance level 0,05 $(a=5 \%)$. Penerimaan atau penolakan hipotesis dilakukan dengan kriteria sebagai berikut: (1) Jika nilai signifikan $>0,05$ maka hipotesis ditolak (koefisien regresi tidak signifikan). Hal ini berarti bahwa secara parsial variabel independen tersebut tidak mempunyai pengaruh yang signifikan terhadap variabel dependen, (2) Jika nilai signifikan $\leq 0,05$ maka hipotesis diterima (koefisien regresi signifikan). 
Hal ini berarti secara parsial variabel independen tersebut mempunyai pengaruh yang signifikan terhadap variabel dependen.

\section{ANALISIS DAN PEMBAHASAN \\ Deskripsi Data}

Gambaran keseluruhan variabel penelitian ditunjukkan pada Tabel 2 berikut ini. Variabel-variabel penelitian meliputi keputusan pembayaran dividen, permintaan investor atau sentimen pasar yang diukur dengan market to book ratio, free cash flow dan profitabilitas, dijelaskan melalui analisis statistik deskriptif pada tabel 3. Tabel 3 menunjukkan statistik deskriptif variabel dependen dan independen yakni jumlah sampel, nilai minimum, nilai maksimum sampel.

$\mathrm{N}$ merupakan jumlah sampel, mean adalah nilai rata-rata dari sampel dan standar deviasi merupakan penyimpangan atau simpangan baku digunakan untuk menunjukkan seberapa jauh nilai yang diperoleh menyimpang dari nilai yang diharapkan. Nilai minimum dan maksimum masing-masing adalah nilai terkecil dan nilai terbesar dari sampel.

Tabel 2

Gambaran Variabel Penelitian

\begin{tabular}{lc}
\hline \hline \multicolumn{1}{c}{ Keterangan } & Jumlah \\
\hline Jumlah Perusahaan BUMN yang terdaftar di BEI tahun 2015 & 20 \\
Data perusahaan BUMN yang tidak tersedia & 10 \\
Jumlah Perusahaan yang menjadi sampel tahun 2010 - 2015 & 110 \\
\hline Sumber: data diolah, 2016 &
\end{tabular}

Tabel 3

Statistik deskriptif variable

\begin{tabular}{cccccc}
\hline \hline Variabel & $\mathbf{N}$ & Minimum & Maximum & Mean & Std.Deviation \\
\hline $\begin{array}{c}\text { Keputusan } \\
\text { pembayaran }\end{array}$ & 110 & 0 & 1 & 0,84 & 0,372 \\
$\begin{array}{c}\text { dividen }(\mathrm{Y}) \\
\text { MB }\end{array}$ & 110 & 1,00 & 279,17 & 6,7030 & 31,01691 \\
FCF & 110 & $-148,08$ & $87.556,23$ & $1.512,978$ & $10.821,63750$ \\
NI & 110 & $-46,27$ & $102.119,67$ & $1.823,398$ & $12.816,771586$ \\
\hline
\end{tabular}

Sumber: Data sekunder diolah (output SPSS), 2006

\section{Keputusan Pembayaran Dividen}

Keputusan pembayaran dividen dalam penelitian ini merupakan variabel dependen yang bersifat kualitatif, oleh karena itu variabel ini harus dikuantitatifkan terlebih dahulu dengan mengambil nilai 1 untuk yang mempunyai atribut dan nilai 0 untuk yang tidak mempunyai atribut. Pembayaran dividen yang dimaksudkan adalah dividen tunai.

Variabel keputusan pembayaran dividen (Y) memiliki nilai minimum 0 merupakan nilai kuantitatif untuk perusahaan yang tidak membayar dividen dan nilai maksimum 1 merupakan nilai kuantitatif untuk perusahaan yang membayar dividen. Nilai rata-rata keputusan pembayaran dividen adalah 0,84 . Angka ini mendekati 1 yang berarti secara rata-rata perusahaan yang membayar dividen lebih banyak dibandingkan yang tidak membayar dividen.

\section{Permintaan Investor akan Dividen}

Permintaan investor (prevailing investors demand) akan dividen diukur dengan market to book ratio (MB). Semakin besar nilai standar deviasi atau besaran nilai sebaran berarti data semakin bervariasi. Nilai rata-rata MB 
adalah sebesar 6,7 kali. Hal ini berarti nilai rata-rata harga pasar saham 6,7 kali dibandingkan nilai bukunya. Nilai minimum MB sebesar 1 kali dimiliki oleh PT Aneka Tambang, Tbk pada tahun 2009. Nilai maksimum MB sebesar 279,17 kali dimiliki oleh PT Perusahaan Gas Negara Tbk pada tahun 2014. Standar deviasi dari MB adalah sebesar 31,016 kali. Semakin besar nilai standar deviasi atau besaran nilai sebaran berarti data semakin bervariasi.

\section{Arus Kas bebas (Free Cash Flow)}

Arus kas bebas dalam penelitian ini diukur dari arus kas bersih aktivitas operasi dikurangi pengeluaran atau belanja modal untuk kegiatan perusahaan. Angka arus kas bebas ditransformasi atau ditampilkan dalam milyaran rupiah sehingga rentang nilai dengan variabel lain tidak terlalu besar. Perusahaan yang mengeluarkan laporan keuangan dalam mata uang Dolar dikonversi ke dalam mata uang Rupiah berdasarkan kurs tengah Bank Indonesia.

\section{Profitabilitas}

Laba bersih diukur dari laba bersih setelah dikurangi pajak. Nilai rata-rata laba bersih sebesar $1.823,4$. Nilai minimum laba bersih sebesar -46,27 dimiliki oleh PT Garuda Indonesia, Tbk pada tahun 2014 dan nilai maksimum sebesar 102.119,67 dimiliki oleh PT Perusahaan Gas Negara, Tbk pada tahun 2013. Pengujian regresi logistik melalui program SPSS.16 memberikan hasil persamaan regresi logistik sebagai berikut. $\mathrm{Y}=0,333+0,186 \mathrm{X}_{1}-0,0007 \mathrm{X}_{2}+0,081 \mathrm{X}_{3}$

Lebih jelasnya dapat dilihat pada Tabel 4 berikut. Evaluasi yang dilakukan untuk memastikan sejauhmana informasi yang diperoleh memenuhi ukuran kebaikan model regresi logistik yang telah dibuat meliputi penilaian seberapa baik model regresi, uji overall model fit untuk mengetahui apakah semua variabel independen di dalam regresi logistik secara serempak memengaruhi variabel dependen.

Berdasarkan nilai Chi-square sebesar 22,941 dengan nilai sig. 0,000 dapat diartikan dengan tingkat keyakinan 95\%, ada variable independen yang berpengaruh pada variabel dependen, sehingga dapat disimpulkan bahwa model dapat digunakan untuk dianalisis lebih lanjut. Uji signifikansi variabel independen secara individual digunakan untuk menguji hipotesis penelitian. Hasil pengujian dapat dilihat pada Tabel 5.

Tabel 4

Variables in the equation

\begin{tabular}{|c|c|c|c|}
\hline Variabel Independen & B & Sig. & $\operatorname{Exp}(B)$ \\
\hline Step H1. MB & 0,186 & 0,391 & 1,205 \\
\hline $1 \mathrm{H} 2 . \mathrm{FCF}$ & $-0,007$ & 0,743 & 0,993 \\
\hline H3 NI & 0,081 & 0,021 & 1,084 \\
\hline Constant & 0,333 & 0,570 & 1,396 \\
\hline
\end{tabular}

Sumber: data diolah (output spss), 2016

\section{Pembahasan}

Prediksi teori Catering dalam Keputusan Pembayaran Dividen Perusahaan BUMN di BEI

Teori catering berfokus pada permintaan atas saham untuk pembayaran dividen dimana prediksi utamanya adalah kecenderungan untuk membayar dividen ter- gantung pada premi dividen yang dapat terukur dari harga saham. Teori catering menekankan bahwa permintaan investor akan dividen dipengaruhi oleh sentimen pasar. Sentimen pasar dalam penelitian ini diukur dengan market to book ratio (MB). Hasil pengujian regresi logistik menunjukkan variabel permintaan investor tidak ber- 
Tabel 5

Hasil pengujian hipotesis

\begin{tabular}{cccccl}
\hline \hline $\begin{array}{c}\text { Hipotesis } \\
\text { Penelitian }\end{array}$ & Koefisien B & Exp(B) & $\begin{array}{c}\text { Prediksi } \\
\text { Arah }\end{array}$ & Signifikansi & Keterangan \\
\hline $\mathrm{H}_{1}$ & 0,186 & 1,205 & Positif & 0,391 & $\begin{array}{l}\text { Hipotesis } \\
\text { ditolak }\end{array}$ \\
$\mathrm{H}_{2}$ & $-0,007$ & 0,993 & Negatif & 0,743 & $\begin{array}{l}\text { Hipotesis } \\
\text { ditolak }\end{array}$ \\
$\mathrm{H}_{3}$ & 0,081 & 1,084 & Positif & 0,021 & $\begin{array}{l}\text { Hipotesis } \\
\text { diterima }\end{array}$ \\
\hline
\end{tabular}

pengaruh signifikan terhadap keputusan pembayaran dividen perusahaan. Hasil penelitian ini membuktikan bahwa perusahaan BUMN yang terdaftar di BEI tidak mempertimbangkan perilaku catering dalam kebijakan dividennya. Hasil penelitian ini mendukung penelitian Ferris et al. (2009) yang menemukan bahwa manajer di negaranegara civil law (termasuk Indonesia) tidak mengikuti preferensi investor akan dividen. Demikian pula halnya dengan Tsuji (2011) yang menyatakan dividen premium bukan merupakan faktor penentu perusahaan industri di Jepang dalam menginisiasi maupun melanjutkan pembayaran dividennya. Hasil penelitian ini tidak mendukung hasil penelitian yang dilakukan oleh Baker dan Wurgler (2004a), Li dan Lie (2005), Neves et al. (2011) dan Albouy et al. (2010).

Baker dan Wurgler (2004a) mengemukakan bahwa permintaan investor akan deviden dengan waktu yang bervariasi disebabkan oleh dividen premium pada saham pembayar dividen relatif terhadap saham bukan pembayar dividen. Fluktuasi ini pada gilirannya memengaruhi perusahaan dalam keputusan perubahan dividen. Li dan Lie (2005) menemukan keputusan perubahan dividen dan besaran perubahan bergantung pada dividen premium pasar modal. Neves et al. (2011) mengungkapkan bahwa perusahaan-perusahaan di zona Euro memberikan kepuasan terhadap sentimen para investornya yang menunjukkan adanya hubungan antara pembayaran dividen dengan teori catering. Albouy et al. (2010) melakukan validasi teori catering dividen melalui survey terhadap para manajer perusahaan yang listing di Perancis. Fatmawati (2015) menemu kan bahwa perusahaan yang terdaftar di-BEI pada Indeks Bisnis 27 mempertimbangkan perilaku catering dalam keputusan pembayaran dividennya. Perusahaan yang termasuk dalam Indeks Bisnis-27 merupakan perusahaan yang memiliki kinerja yang telah diseleksi secara fundamental, teknikal dan akuntabilitas. Kriteria fundamental meliputi laba bersih, return on Asset (ROA) return on Equity (ROE) dan untuk sektor perbankan mempertimbangkan faltor LDR dan CAR. Kriteria teknikal mempertimbangkan nilai, volume dan frekuensi transaksi serta jumlah hari transaksi dan kapitalisasi pasar. Aspek akuntabilitas dengan mempertimbangkan peningkatan kua litas pemilihan saham-saham yang termasuk dalam indeks Bisnis-27 dengan membentuk komite yang memberikan opini dalam hal akuntabilitas, tata kelola perusahaan yang baik maupun kinerja saham.

\section{Pengaruh Free Cash Flow (FCF) terhadap Keputusan Pembayaran Dividen Perusaha- an}

Pengujian hipotesis kedua menunjukkan hasil positif untuk free cash flow terhadap keputusan pembayaran dividen perusahaan. Nilai positif terlihat pada Exp (B) sebesar 0,993 namun memiliki signifikansi sebesar 0,743 . Hal ini mengandung arti free cash flow tidak berpengaruh secara signifikan terhadap keputusan pembayaran dividen perusahaan. Hasil analisis data arus kas bebas yang dilakukan perusahaan BUMN 
sepanjang periode pengamatan tidak mendukung hipotesis kedua yang menyatakan FCF secara signifikan berpengaruh positif terhadap keputusan pembayaran dividen perusahaan. Beberapa faktor yang menyebabkan pengaruh arus kas bebas tidak signifikan dalam keputusan pembayaran dividen perusahaan. Pertama, terdapat perusahaan yang tidak membayar dividen walaupun memiliki arus kas bebas yang positif seperti PT Garuda Indonesia (Persero) dan PT Krakatau Steel (Persero). Kedua, perusahaan-perusahaan yang sudah mapan, memiliki kapitalisasi pasar yang besar dengan kebijakan pembayaran dividen stabil dilakukan dalam enam tahun berturut-turut cenderung melakukan pembayaran dividen walaupun memiliki arus kas bebas negatif, seperti PT Adhi Karya (Persero), PT Timah (Persero), PT Bank Negara Indonesia (Persero) dan PT Bank Tabungan Negara (Persero), PT Bank Rakyat Indonesia (Persero), PT Jasa Marga (Persero) dan PT Krakatau Steel (Persero).

PT Aneka Tambang (Persero) sendiri selama 5 tahun berturut-tururt sejak tahun 2009 rutin membagikan dividen, namun pada tahun 2015 tidak membagikan dividen. Berdasarkan data penelitian arus kas bebas tahun sebelumnya menunjukkan nilai negatif demikian pula kinerja perusahaan masih rugi. Berikut data perusahaan yang membayarkan dividen baik pada kondisi arus kas bebas positif maupun negatif.

Tabel 6

Data Perusahaan Pembayar Dividen Enam (6) Tahun Berturut-Turut Kondisi Arus Kas Bebas Positif maupun Negatif

Dalam Milyar Rupiah

\begin{tabular}{cccccccc}
\hline \hline \multirow{2}{*}{ No } & \multirow{2}{*}{ Perusahaan } & $\mathbf{2 0 0 9}$ & $\mathbf{2 0 1 0}$ & $\mathbf{2 0 1 1}$ & $\mathbf{2 0 1 2}$ & $\mathbf{2 0 1 3}$ & $\mathbf{2 0 1 4}$ \\
& & $-153,18$ & $-37,17$ & 504,59 & 128,5 & 154,15 & -1.567 \\
1 & PT Adhi Karya & 640 & -14.807 & 14.665 & 5.814 & -8.485 & $-1.976,6$ \\
2 & PT Bank BNI & 20.332 & 53.824 & 15.018 & -3.440 & 2.451 & 81.865 \\
3 & PT Bank BRI & & -2.832 & 4.555 & 1.492 & 1.108 & -2.240 \\
4 & PT Bank BTN & 1.048 & -330 & 176.268 & 1.633 & 1.811 & 1.620 \\
5 & PT Jasa Marga & -634 & 333 & -352 & 589 & -1.214 & -1.063 \\
6 & PT Timah & 840 & 182 & 675 & 9.031 & -315 & -178 \\
7 & PT Wijaya Karya & & & & & & \\
\hline
\end{tabular}

Sumber : data sekunder diolah (annual report), 2016

Temuan penelitian ini mendukung penelitian Arilaha (2009), Hadianto dan Herlina (2010), Fatmawati (2015) dimana variabel free cash flow tidak berpengaruh terhadap kebijakan dividen. Penelitian ini menemukan bahwa besar kecilnya arus kas bebas tidak mempengaruhi tinggi rendahnya pembagian dividen. Apabila perusahaan menginginkan untuk memaksimumkan kekayaan pemegang saham dengan membagikan dividen sedangkan kondisi arus kas tidak memungkinkan, perusahaan dapat menggunakan pendanaan eksternal. Sebaliknya hasil penelitian ini tidak mendukung temuan Chaplinsky dan Niehaus (1993),
Holder et al., (1998) dan Neves et al., (2011) yang membuktikan hubungan positif signifikan antara dividen dan arus kas bebas. Neves et al. (2011) mengemukakan bahwa interaksi antara perilaku catering dan karakteristik perusahaan yang memiliki tingkat arus kas bebas (free cash flow) lebih kuat dalam melayani sentimen para investornya. Demikian pula penelitian Lucyanda dan Lilyana (2012) yang menemukan pengaruh yang signifikan antara free cash flow terhadap pembayaran dividen.

Pengaruh Profitabilitas terhadap Keputusan Pembayaran Dividen Perusahaan 
Hipotesis ketiga menyatakan bahwa profitabilitas berpengaruh positif terhadap keputusan pembayaran dividen perusahaan. Hasil pengujian memberikan nilai NI pada $\operatorname{Exp}(B)$ sebesar 1.084 dengan tingkat signifikansi 0,021, artinya variabel NI secara signifikan berpengaruh positif terhadap keputusan perusahaan membayar dividen.

Berdasarkan hasil pengujian hipotesis ini dapat disimpulkan bahwa perusahaan yang memutuskan untuk melakukan pembayaran dividen memiliki karakteristik profitabilitas yang tinggi. Dengan demikian penelitian ini mendukung penelitian yang dilakukan oleh Baker dan Powell (1999), DeAngelo, DeAngelo dan Skinner (2004), Suharli (2007), Dennis dan osobov (2008), Hadianto dan Herlina (2010) serta Kurniasih (2011). DeAngelo, DeAngelo dan Skinner, (2004) dalam Ferris et al. (2009) menyatakan earnings adalah faktor penentu dividen. Kebijakan dividen suatu perusahaan sangat dipengaruhi oleh tingkat profitability pada periode yang berjalan dan periode-periode sebelumnya (Denis dan Osobov, 2008). Perubahan pembayaran dividen dipengaruhi oleh laba tahun berjalan, laba periode sebelumnya, perubahan dividen sebelumnya dan perubahan laba tahun berjalan (Kurniasih, 2011).

\section{SIMPULAN DAN SARAN Simpulan}

Berdasarkan hasil temuan penelitian pengaruh teori catering dan karakteristik perusahaan dalam keputusan pembayaran dividen di Bursa Efek Indonesia yang telah dipaparkan pada bab sebelumnya maka dapat diambil kesimpulan bahwa teori Catering tidak berpengaruh dalam keputusan pembayaran dividen ditandai oleh permintaan investor tidak berpengaruh signifikan terhadap keputusan pembayaran dividen perusahaan. Dengan demikian, perusahaan publik BUMN yang terdaftar di Bursa Efek Indonesia tidak mempertimbangkan perilaku catering dalam keputusan pembayaran dividen. Teori catering menekankan pada permintaan investor akan dividen dipengaruhi oleh sentimen pasar. Manajer akan melayani permintaan investor akan dividen ketika investor menempatkan harga saham yang lebih tinggi pada perusahaan pembayar dividen.

Karakteristik keuangan perusahaan dalam keputusan pembayaran dividen perusahaan publik BUMN yang terdaftar diBEI adalah perusahaan yang memiliki profitabilitas yang tinggi. Penentu penting dari kebijakan dividen suatu perusahaan adalah tingkat earnings saat ini dan harapan earnings untuk masa yang akan datang.

\section{Saran}

Penelitian selanjutnya dapat mengambil obyek lain pada perusahaan publik di BEI sehingga dapat memberikan informasi yang lebih luas dan lebih komprehensif berkaitan dengan implikasi teori catering. Dengan demikian, dapat pula diperoleh perilaku catering dividen dari setiap sektor perusahaan publik lainnya. Penelitian selanjutnya dapat menggunakan model analisis lain maupun menambah variabel lain yang menjadi karakteristik keuangan perusahaan dalam keputusan pembayaran dividen seperti tingkat hutang, ukuran perusahaan dan rasio retained earning to total asset (RE/TA).

\section{DAFTAR PUSTAKA}

Albouy, M., R. Bah, C. Bonnet, dan D. Thévenin. 2010. The Perception of Dividends by French Managers: An International Comparison. Working Paper. Université de Grenoble 2.

Arilaha, M. A. 2009. Pengaruh Free Cash Flow, Profitabilitas, Likuiditas dan Leverage terhadap Kebijakan Dividen. Jurnal Keuangan dan perbankan 13(1): 7887.

Baker, M. dan J. Wurgler. 2004a. A Catering Theory of Dividends. The Journal of Finance 59(3): 1125-1165.

-2004b. Appearing and Disappearing Dividends: The link to Catering Incentives. Journal of financial economics 73(2): 271-288. 
Baker, H. K. dan G. E. Powell. 1999. How Corporate Managers View Dividend Policy. Journal of Business Economics 38(2): 17-35.

Bhattacharya, S. 1979. An Exploration of Nondissipative Dividend-Signaling Structures. Journal of Financial and Quantitative Analysis 14(4): 667-668.

Bhattacharyya, N. 2007. Dividend Policy: A Review. Managerial Finance 33(1): 4-13.

Chaplinsky, S. dan G. Niehaus. 1993. Do Inside Ownership and Leverage Share Common Determinants?. Quarterly Journal of Business and Economics 32(4): 51-65.

DeAngelo, D. dan L. DeAngelo. 2006. The Irrelevance of the MM Dividend Irrelevance Theorem. Jurnal of Financial Economics 79(2): 293-315.

Denis, D. J. dan I. Osobov. 2008. Why Do Firm's Pay Dividends? International Evidence on the Determinants of Dividend Policy. Journal of Financial Economics 89(1): 62-82.

Fama, E. F. dan H. Babiak. 1968. Dividend Policy: An Empirical Analysis. Journal of the American Statistical Association 63(324): 1132-1161.

Ferris, S. P., N. Jayaraman, dan S. Sabherwal. 2009. Catering Effects in Corporate Dividend Policy: The International Evidence. Journal of Banking $\mathcal{E}$ Finance 33(9): 1730-1738.

Frankfurter, G. M. dan B. G. Wood Jr. The Evolution of Corporate Dividend Policy. Journal of Financial Education 23: 16-33.

Gordon, M. J. 1963. Optimal Investment and Financing Policy. The Journal of Finance 18(2): 264-272.

Handary A. R., N. Lukviarman, dan R. Febrianto. 2008. The Correlation of Catering Incentives to Stock Return: A Test of Catering Theory of Dividend. The Indonesian Journal of Accounting Research 11(1).

Hadianto, B. dan Herlina. 2010. Prediksi Arus Kas Bebas, Kebijakan Utang dan Profitabilitas terhadap Kemungkinan
Dibayarkannya Dividen. Jurnal Manajemen Bisnis 3(1): 53-74.

Holder, M. E., F. W. Langrehr, dan J. L. Hexter. 1998. Dividend Policy Determinants: An Investigation of the Influences of Stakeholder Theory. Financial Management 27(3): 73-82.

Indonesia Finance Today. 2012. Surviving Crisis a Quest for Prosperity: Indonesia's Economic Review 2004-2012.

Jensen, M. 1986. Agency Costs of Free Cash Flow, Corporate Finance, and Takeovers. The American Economic Review 76(2): 323-329.

Kurniasih, A. 2011. Analisis Karakteristik, Perilaku, Faktor Penentu dan Reaksi Pasar terhadap Kebijakan Perusahaan Tercatat di Bursa Efek Indonesia. Disertasi. Program Pasca Sarjana Institut Pertanian Bogor. Bogor.

Li, W. dan E. Lie. 2005. Dividend Changes and Catering Incentives. Journal of Financial Economics 80(2): 293-308.

Lintner, J. 1956. Distribution of Incomes of Corporations Among Dividends, Retained Earnings, and Taxes. The American Economic Review 46(2): 97-113.

Lintner, J. 1962. Dividends, Earnings, Leverage, Stock Prices and the Supply of Capital to Corporations. The Review of Economics and Statistics 44(3): 243-269.

Lucyanda, J. dan Lilyana. 2012. Pengaruh Free Cash Flow dan Struktur Kepemilikan terhadap Dividen Payout Ratio. Jurnal Dinamika Akuntansi 4(2): 129-138.

Miller, M. H. dan F. Modigliani. 1961. Dividend Policy, Growth, and the Valuation of Shares. The Journal of Business 34(4): 411-433.

Neves, E., J. Pindado, C. de la Torre. 2011. Dividens: New Evidence on the Catering Theory. http://www.eco.uva.es/ empresa/uploads/dt_14_06.pdf. Diakses tanggal 5 Mei 2013.

Suharli, M. 2007. Pengaruh Profitability dan Investment Opportunity Set terhadap Kebijakan Dividen Tunai dengan Likui- 
ditas sebagai Variabel Penguat (Studi pada Perusahaan yang Terdaftar di Bursa Efek Jakarta Periode 2002-2003). Jurnal Akuntansi dan Keuangan 9(1): 9-17. Sutrisno. 2009. Manajemen Keuangan Teori, Konsep, dan Aplikasi. Ekonisia. Yogyakarta.

Tsuji, C. 2011. Exploring the Corporate Dividend Payment Behavior of the Japanese Chemicals Industry Firms. The Open Business Journal 4: 1-13.
Warsono. 2003. Manajemen Keuangan Perusahaan. Edisi Ketiga. Bayumedia Publishing. Malang.

Wild, J., J. Subramanyam, dan F. Halsey. 2007. Financial Statement Analysis. Edisi 10. McGraw-Hill. New York. 